scheme as Prof. Armstrong very properly suggests. The would-be disciple of science is thunderstruck (as probably not a few teachers of science were when they first saw the scheme), but the novelty of the situation, the sight of new appliances and strange results, enable him to pull himself together, and his interest for a time keeps up. Presently he is asked to conduct for himself some simple steps of deductive reasoning; he fails, the whole business is a new world to him, and in the misery of his wishfulness to do something, he beseechingly asks for more dry facts to devour. What is the ultimate result? If science is to be taught effectually it must begin with the earliest years of the educational career, and there is surely no subject that lends itself $\mathrm{m}$ ore appropriately to the youthful mind. Children delight to talk of flowers, of insects, of the wonders of nature; they are ever asking suggestive questions; they are indefatigable collectors of objects of beauty; the Kindergarten system has acknowledged that the child is an orderly being delighting in symmetry and colour. Yet we increase his vocabulary by the word "star" and fail to tell him anything of the wonders of stardom. Why, our very fairy tales are based on just such fabric! To effect this early introduction of science the very best and most considerate teaching is required, as indeed it is a much more difficult task to guide the young student's thoughts than to guide the veteran student's reading. We want, further, a well thought-out progressive srheme of simple general science which shall be suggestive to the teacher of the course to be pursued. To draw up such a scheme is, I am quite aware, not a matter of moments : it would require the association of many minds and many sympathies.

Something in this direction has been done in France, and good text-books are to be found in the English science primers and in Paul Bert's Book of General Science for the Young; text-books, however, are not an immediate want-for the matter of that, the pupil may make his own-we do, however, want that which will help the conscientious teacher to see how he may make the teaching of science interesting, intelligent, and above all progressive. We cannot afford to wait for unintelligent teaching to die a natural death, remembering that there is in England no criterion that the teacher in the middle-class school can teach, that teaching does not pay in examinations, that the dry-bones method lends itself most readily to school discipline, and finally, that the subjects chiefly taught are of such a nature as almost to preclude any other method with the young. Under the present régime science is not a growth, it is a graft, and a graft, it is to be feared, of a most unfortunate nature ; the sooner it develops roots of its own the better. It is, under the circumstances, no cause for wonder that the more advanced student flounders over common general principles. I have confined my remarks, for the : ake of definiteness, to middle-class schools, but they are, I believe, with unessential variation, applicable to the general question of the teaching of science. G. H. BAILEY

Heiclelberg, February 3

\section{Barrenness of the Pampas}

I AM anxious to add a few further remarks on this interesting subject. It was during its investigation that I was so deeply impressed with the desperate struggle for existence which characterises the bordering fertile zones. I could there watch the contest on the very battle-field itself, and for that purpose I established myself for some months in the north of Uruguay, away from all other habitation, among the wooded banks and lagunes of the River Arapey. This river, though normally a quiet stream, is subject to tropical floods, during which the water rose often thirty fcct in eight hours. The "monte," or fertile wooded belt on each side, is intersected with ravines and lagunes teeming with animal and vegetable life of singular interest. The alligator, carpincho, myopotamus, nutria and other and numberless snakes thrive in the marshy swames, while in the woods we met with the puma, the jaguar, the great lizard, the Podinama, the Nasua socialis, and numerous other singular animals and birds described in my little book. But it was among the flora that the principle of natural selection was mo:t prominently displayed. In such a district, overrun with rodents and escaped cattle, subject to floods that carried away whole islands of botany, and e pecially to droughts that dried up the lakes, and almost the river itself, no ordinary plant could live, even on this rich and watered alluvial débris. The only plants that escaped the cattle were such as were either poisonous, or thorny, or resinous, or indestructibly tough. Hence we has only a great development of solanums, talas, acacias, euphorbias, and laurels. The buttercup is replaced by the little poisonous yellow oxalis with its viviparous buds, the passion-flowers, asclepiads, bignonias, convovuluses, and climbing leguminous plants escape both floods and cattle by climbing the highest trees and towering over head in floods of bloom. The groundplants are the portulacas, turneras, and cenotheras, bitter and ephemeral on the arid rock, and almost independent of any other moisture than the heavy dews. The pontederias, alismas, and plantago, with grasses and sedges, derive protection from the deep and brilliant pools; and though at first sight the "monte" doubtless impresses the traveller as a scene of the wildest confusion and ruin, yet, on closer examination, we found it far more remarkable as a manifestation of harmony and law and a striking example of the marvellous power which plants, like animals, possess of adlapting themselves to the local peculiarities of their habitat, whether in the fertile shades of the luxurious "monte" or on the arid, parched-up plains of the treeless Pampas.

Great Marlow

\section{Recent Earthquakes}

With reference to the statement in NATURE, vol. xxxi. p. 262, that the earthquake of December' 25,1884 , was registered by the magnetic variation instruments in London, permit me to inform you that an effect was also noticed on a curve of the magnetograph at the Imperial Marine Observatory, Wilhelmshaven. But while at London declination and bifilar were specially affected, here only the Lloyd's magnetic balance, the instrument for vertical intensity, was set in oscillation, first at $9 \mathrm{~h} .52 \mathrm{~m}$. p.m. local time. Full details will be published in the Zeitschrift of German Meteorology.

Wilhelmshaven, February 6 Dr. M. EsCHENHAGEN

MR. W. A. SANFORD, in NATURE of January 29, p. 289 , says on the above subject:--"It would be interesting to know whether anything of the same kind [as described in his letter] had been observed elsewhere at the same time." I have been collecting observations on this subject for a continuation of my paper on earthquakes in Devon, published in the Transactions of the Devonshire Association. The Vicar of Bampton has very kindly given me his experience of the earthquake, as the wave appeared to have passed very near, if not directly under, his house. Bampton is seven miles north of Tiverton, and about a mile inside the junction of the Carboniferous and the Devonian systems, situate on a rather large patch of limestone. The time the earthquake occurred there was $8.42 \mathrm{p} . \mathrm{m}$. In the drawingroom at the vicarage it appeared as if a heavy traction-engine was passing close to the window; the window faces eastward. In the kitchen the servants were greatly alarmed by a rumbling noise and a shaking under the floor. Some of the Vicar's neighbours say they heard a report, and houses with cellars under them and higher felt the shaking more; some persons who were up stairs, thinking that it was some explosion, rushed down stairs and out of doors. The effects were also felt at Shillingford, two miles distant, and also at Combehead, one and a half mile distant. The porters at the station describe it as like a heavily-laden mineral train passing. The only damage done at Bampton was a piece of wall was thrown down. This was undonbtedly the same shock or seismic wave as mentioned by Mr. Sanford as occurring on the night of Thursday, January 22, and would appear to have travelled from east to west.

\section{Devon and Exeter Institution, Exeter}

\section{EDWARD PARFITT}

\section{Loligopsis ellipsoptera}

Coun you allow me space to ask whether any of your readers can give me a clue to the present locality of the type-specimen of Loligopsis cllipsoptera, Adams and Reeve, obtained during the voyage of the Samarang; and also to state how grateful I should be to any one who can lend me specimens of that genus or of others allied to it?

WM, E. HOYLE

Challenger Expedition Office, 32, Queen Street, Edinburgh, February 9

L. WRAY, JUN.--Your surposed dragon-fly belongs to the family Ascalaphida, allied to the ant-lions. 